\title{
Detached Leaf Test for Evaluation of Resistance to Powdery Mildew in Pepper
}

\author{
Nuray Özer ${ }^{1 *}$, Ali Kün² and Hülya İllbi ${ }^{3}$ \\ ${ }^{1}$ Faculty of Agriculture, Namık Kemal University, Turkey \\ ${ }^{2}$ Antalya Tarım Hybrid Seeds Corporations, Turkey \\ ${ }^{3}$ Faculty of Agriculture, Ege University, Turkey
}

Submission: February 14, 2018; Published: March 12, 2018

*Corresponding author: Nuray Özer, Namık Kemal University, Faculty of Agriculture, Department of Plant Protection, Tekirdağ, Turkey, Email: nurayozer62@gmail.com

\begin{abstract}
Powdery mildew caused by Leveillula taurica (Lév) G. Arn. is a quite serious disease of pepper varieties (Capsicum spp.) worldwide. The use of resistant genotypes can control the disease. Tests of resistance against powdery mildew during pepper breeding studies have been carried out by directly brushing the conidia or spraying a conidia suspension on whole potted plants grown in the greenhouse. High amounts of inoculum, labour and large experimental areas are needed for these tests. The aim of this study was to investigate the possibility of using detached leaves for resistance evaluation. Detached leaves of a sensitive cultivar (Moonset F1) were placed on two different media (water agar and moistened filter paper) in petri dishes, were inoculated using three different methods (direct brushing conidia, spraying conidia suspension in distilled water, and in sterile distilled water). Inoculated leaves were incubated under two different conditions $\left(16^{\circ} \mathrm{C}\right.$ for $24 \mathrm{~h}$ in dark, then $22^{\circ} \mathrm{C}$ for $14 \mathrm{~h} \mathrm{light} / 10 \mathrm{~h}$ dark, and $21^{\circ} \mathrm{C}$ for $12 \mathrm{~h}$ light $/ 12 \mathrm{~h}$ dark) in a climatically controlled room. The methods were combined with each other. The combination of water agar and moistened filter paper with inoculation by brushing conidia and spraying conidia suspension in distilled water at the second incubation condition gave infected leaf areas of $50 \%$ or more with powdery mildew at 25 day after inoculation. The authors suggest that detached leaves might be very practical to assess the resistance of pepper lines against to powdery mildew disease for breeding programmes.
\end{abstract}

Keywords: Detached leaves; Pepper (Capsicum annuum); Powdery mildew; Resistance test

\section{Introduction}

Powdery mildew caused by Leveillua taurica (Lev.) G. Arn. [anamorph: Oidiopsis taurica (Lev.) Salmon] causes economic yield losses in several groups of plants in addition to pepper varieties (Capsicum spp.) [1]. The fungus is an obligate biotrophic pathogen and needs living plants to develop and reproduce. In contrast to other powdery mildew genera, the germinated conidia of Leveillula and Phyllactinia develop adhesion bodies instead of appresoria to attach to the leaf surface. Infection hyphae penetrate host plants through stomata on the abaxial leaf surface, produce haustoria in the mesophyll cell and grow as endophyte [1]. Mildew colonies develop on the abaxial surface of infected leaves. Endophytic growth of the pathogen hinders the efficacy of chemical control [2,3]. Additionally, indiscriminate use of fungicides has a negative impact on the environment and allows emergence of fungicide-resistant strains [4,5]. Breeding of resistant varieties appears to be the best control practice. Tests for resistance of pepper genotypes against powdery mildew disease are one of the main objectives for a breeding program. Assessments of powdery mildew resistance are performed on whole potted plants in a greenhouse. The abaxial surface of healthy plants with 45-60 days growth are inoculated by pressing gently sporulated areas of old infected leaves [6-7], by transferring the spores with a small brush [7-9]), and by spraying a conidia suspension $\left(10^{4}-10^{6}\right.$ conidia/ml $)$ in sterile distilled water or tap water $[3,5,7,10-16]$. In some studies, inoculation of plants was carried out by placing infected plants in the vicinity of healthy plants [17-22]. The plants were maintained at $16^{\circ} \mathrm{C}$ for $24 \mathrm{~h}$ in dark, then at $22^{\circ} \mathrm{C}$ for $14 \mathrm{~h}$ light and at $16^{\circ} \mathrm{C}$ for $10 \mathrm{~h}$ dark (3) or at day temperature $\left(21^{\circ} \mathrm{C}, 25^{\circ} \mathrm{C}\right)$ and night temperature $\left(19^{\circ} \mathrm{C}, 22^{\circ} \mathrm{C}\right)$ after inoculation $[5,9,14-15]$. Some authors kept pepper plants for $24 \mathrm{~h}$ in plastic cages after inoculation [5,13,1516]. Tests for resistance of pepper genotypes to powdery mildew throughout a breeding program under greenhouse conditions need high amounts of inoculum, labour, time and large experimental area. This study aims to examine the use of detached leaves placed on petri dishes by combining different media, inoculation methods and temperature conditions.

\section{Materials and Methods}

A pepper cultivar (Moonset F1) very sensitive to powdery mildew was grown in a disease-free greenhouse for 80 days. 
Detached leaves of the cultivar were used during the experiments. Leaves were surface-sterilized with $70 \%$ ethanol, then rinsed in sterile distilled water. After drying on sterile filter paper, leaves were placed bottom side up in petri dishes containing water agar (20g/l) supplemented with $30 \mathrm{mg} / \mathrm{l}$ benzimidazole (A) or three layers of moistened filter paper (B) (Table 1). Two sterile glass slides were put on the agar or filter paper to prevent contact of the leaves with media. Petioles were wrapped with sterilized wet filter paper to extend leaf viability. Powdery mildew inoculums were collected from infected pepper plants in a greenhouse in Antalya/Turkey. Leaves were inoculated with conidia using three different methods: slight brushing of conidia from sporulating zones onto the leaf (a), spraying a conidia suspension $\left(1 \times 10^{5}\right.$ conidia/ml) in distilled water (b) and in sterilized distilled water (c). Petri dishes sealed with parafilm were kept in two different conditions: $16{ }^{\circ} \mathrm{C}$ for $24 \mathrm{~h}$ in dark, then at $22{ }^{\circ} \mathrm{C}$ for $14 \mathrm{~h}$ light/10h dark (I) and $21{ }^{\circ} \mathrm{C}$ for $12 \mathrm{~h}$ light/12h dark in a climatically controlled room (II). The methods were combined with each other and all combinations were repeated three times. Observations for sporulation were made at weekly intervals.

Table 1: Media, inoculation and incubation conditions used for method combinations

\begin{tabular}{|c|c|c|}
\hline Media & Inoculation & $\begin{array}{c}\text { Incubation } \\
\text { Condition }\end{array}$ \\
\hline A: Water Agar & $\begin{array}{c}\text { a: Directly brushing } \\
\text { conidia }\end{array}$ & $\begin{array}{c}\text { I: } 16^{\circ} \mathrm{C} \text { for } 24 \mathrm{~h} \text { in } \\
\text { dark, then at } 22^{\circ} \mathrm{C} \\
\text { for } 14 \mathrm{~h} \text { light } / 10 \mathrm{~h} \\
\text { dark }\end{array}$ \\
\hline & $\begin{array}{c}\text { b: Spraying conidia } \\
\text { suspension in } \\
\text { distilled water }\end{array}$ & $\begin{array}{c}\text { II: } 21^{\circ} \mathrm{C} \text { for } 12 \mathrm{~h} \\
\text { light } / 12 \mathrm{~h} \text { dark }\end{array}$ \\
\hline & $\begin{array}{c}\text { c: Spraying conidia } \\
\text { suspension in sterile } \\
\text { distilled water }\end{array}$ & \\
\hline $\begin{array}{c}\text { B: Moistened filter } \\
\text { paper }\end{array}$ & (a) as in A & (I) as in A \\
\hline & (b) as in A & (II) as in A \\
\hline & (c) as in A & \\
\hline
\end{tabular}

\section{Results and Discussion}

First limited sporulation was observed on leaves in the method combination AbI at one week after inoculation, but symptoms then developed slowly (Table 2). Sporulation was detected on leaves of method combinations AaII, AbII, BaII and BbII at 15 days after inoculation. $40 \%$ and $25 \%$ of leaf area were covered with sporulation when leaves were inoculated by directly brushing conidia and spraying with conidia suspension in distilled water, respectively (Figure 1). The method combinations AcII and BcII gave less sporulation compared with AaII and BaII (Figure 2).

The method combinations AaII, AbII, BaII and BbII gave infected leaf areas of $50 \%$ or more with powdery mildew at 25 days after inoculation (Figure 3). There were no differences among the media used for sporulation. However, more brownish areas on leaves that were placed on moistened filter paper or inoculated by brushing conidia were observed at 25 days after inoculation as compared with other methods under incubation condition II. Infected leaf areas of $40 \%$ were observed for AcII and BcII at 25 days after inoculation (Figure 3). Disease evaluations on pepper plants were realized at 21-50 days after inoculation by spraying conidia $[3,7,9,11,13-16]$ and at flowering time after inoculation by placing infected plants near to healthy plants [17-22] under greenhouse conditions During these evaluations the genotypes, which had infected leaf areas of 40.1 $-51 \%$ or more, were accepted as highly susceptible [7, 18-21]. In the current study, infected leaf areas of $51 \%$ or more were as obtained with method combinations AaII, AbII, BaII, BbII at 25 days after inoculation. To our knowledge, this is the first time such a method is reported for evaluation of resistance in pepper against powdery mildew. Our method has some advantages: a-it is rapid, easy and requires little space, b- it permits testing a great number of genotypes at once, $c$ - it is possible to organize the experiment with many replicates to justify the results, d-optimum conditions for pathogen growth can be developed, and thus, the experiment is not affected by other factors in greenhouse or field. However, moistened filter paper media and inoculation by brushing conidia had a disadvantage by causing browning on leaves.

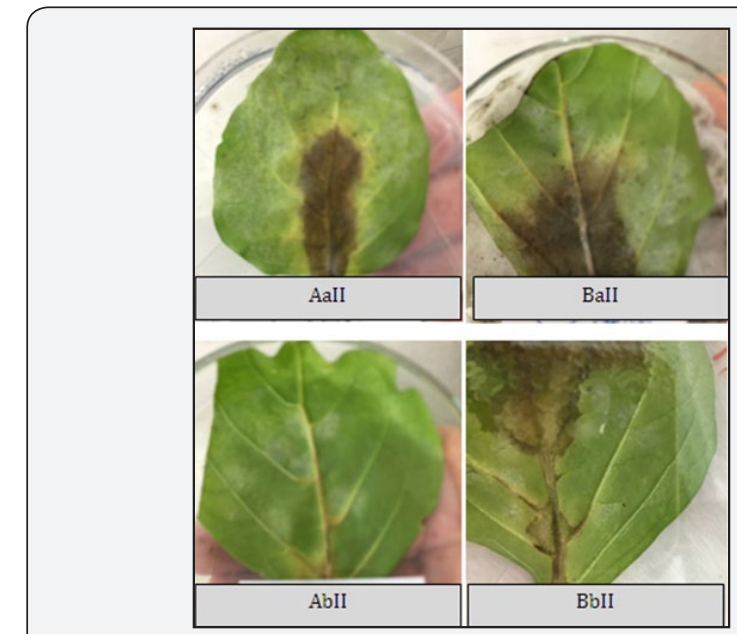

Figure 1: Sporulation observed in several method combinations at 15 days after inoculation.



Figure 2: Sporulation observed in method combinations Acll and Bcll at 15 days after inoculation. 


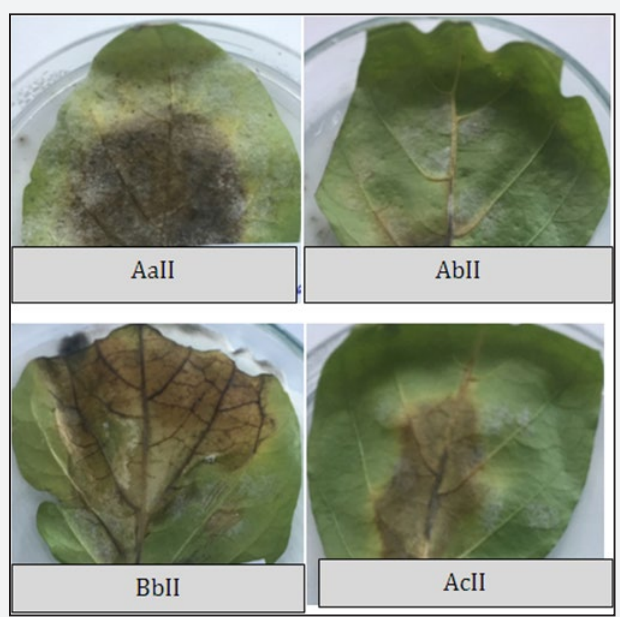

Figure 3: Sporulation observed in several method combinations at 25 days after inoculation.

Table 2: Infected leaf area at several days after inoculation for different methods.

\begin{tabular}{|c|c|c|c|}
\hline \multirow{2}{*}{ Method } & \multicolumn{3}{|c|}{ Infected Leaf Area (\%) at Days After Inoculation } \\
\cline { 2 - 4 } & $\mathbf{7 d}$ & $\mathbf{1 5 d}$ & $\mathbf{2 5 d}$ \\
\hline AaI & 5 & 10 & 10 \\
\hline AaII & - & 40 & 95 \\
\hline AbI & - & 5 & 10 \\
\hline AbII & - & 25 & 90 \\
\hline AcI & - & - & 5 \\
\hline AcII & - & 15 & 40 \\
\hline BaI & - & 5 & 10 \\
\hline BaII & - & 40 & 95 \\
\hline BbI & - & 5 & 10 \\
\hline BbII & - & 25 & 80 \\
\hline BcI & - & - & 5 \\
\hline BcII & - & 15 & 40 \\
\hline
\end{tabular}

\section{Conclusion}

The detached leaf method reported here is suitable to evaluate resistance in pepper against powdery mildew. It has potential to be extended for other hosts of L. taurica. However, our studies have been continuing to ameliorate the moistened filter paper media and brushing conidia inoculation. In addition, further studies are needed to compare the results of detached leaves with greenhouse and field evaluations using different genotypes.

\section{Acknowledgement}

The authors acknowledge Martha Rowe (University of Nebraska-Lincoln) for improving the language and for useful remarks.

\section{References}

1. Braun U, Cook RTA (2012) Taxonomic Manual of the Erysiphales (Powdery Mildews). CBS-KNAW Fungal Biodiversity Centre, Utrecht, The Netherlands, p. 707.
2. Elad Y, Messika Y, Brand M, David DR, Sztejnberg A (2007) Effect of Colored Shade Nets on Pepper Powdery Mildew (Leveillula taurica). Phytoparasitica 35(3): 285-299.

3. Lefebvre V, Daubèze M, van der Voort JR, Peleman J, Bardin M, et al. (2003) QTLs for resistance to powdery mildew in pepper under natural and artificial infections. Theor Appl Genet 107(4): 661-666.

4. Jones WB, Thomson SV (1987) Source of inoculum, yield, and quality of tomato as affected by Leveillula taurica. Plant Disease 71(3): 266-268.

5. Zheng Z, Nonomura T, Appiano M, Pavan S, Matsuda Y, et al. (2013a) Loss of function in Mlo orthologs reduces susceptibility of pepper and tomato to powdery mildew disease caused by Leveillula taurica. PLoS One 8: e70723.

6. Clerk GC, Ayesu-Offei N (1967) Conidia and Gonidial Germination in Leveillula taurica (Lèv.) Arn. Annals of Botany 31(124): 749-754.

7. Kim DH, Park JH, Lee JS, Han KS, Han YK, et al. (2009) Effect of temperature, relative humidity on germination and development of powdery mildew (Leveillula taurica) on pepper and its inoculation method. Research in Plant Disease 15(3): 187-192.

8. Guzman-Plazola RA, Davis RM, Marois JJ (2003) Effects of relative humidity and high temperature on spore germination and development of tomato powdery mildew (Leveillula taurica). Crop Protection 22 (10): $1157-1168$.

9. Albert R, Künstler A, Lantos F, Ádám AL, Király L (2017) Grafttransmissible resistance of cherry pepper (Capsicum annuum var. cerasiforme) to powdery mildew (Leveillula taurica) is associated with elevated superoxide accumulation, NADPH oxidase activity and pathogenesis-related gene expression. Acta Physiologiae Plantarum 39: 53.

10. Bai Y, Huang, CC, van der Hulst R, Meijer-Dekens F, Bonnema G, et al. (2003) QTLs for tomato powdery mildew resistance (Oidium lycopersici) in Lycopersicon parviflorum G1.1601 co-localize with two qualitative powdery mildew resistance genes. Molecular Plant Microbe Interaction 16(2):169-176.

11. de Souza VL, Café-Filho AC (2003) Resistance to Leveillula taurica in the genus Capsicum. Plant Pathology 52(5): 613-619.

12. Elad Y, Messika Y, Brand M, David DR, Sztejnberg A (2007) Effect of microclimate on Leveillul taurica powdery mildew of sweet pepper. Phytopathology 97(7): 813-824.

13. Sudha A, Lakshmanan P (2009) Integrated disease management of powdery mildew (Leveillula taurica (Lev.) Arn.) of Chilli (Capsicum annuum L.). Archives of Phytopathology and Plant Protection 42(4): 299-317.

14. Cerkauskas RF, Ferguson G, Banik M (2011) Powdery mildew (Leveillula taurica) on greenhouse and field peppers in Ontario - host range, cultivar response and disease management strategies. Canadian Journal of Plant Pathology 33(4): 485-498.

15. Zheng Z, Nonomura T, Bóka K, Matsuda Y, Visser RGF, et al. (2013) Detection and quantification of Leveillula taurica growth in pepper leaves. Phytopathology 103(6): 623-632.

16. Arthikala MK, Nanjareddy K, Lara M, Sreevathsa R (2014) Utility of a tissue culture-independent Agrobacterium-mediated inplanta transformation strategy in bell pepper to develop fungal disease resistant plants. Scientia Horticulturae 170: 61-69

17. Allagui MB, Palloix A, Hamza N (1995) Résistance du Piment ( Capsicum sp.) à Leveillula taurica: évolution de l'épidémie avec la croissance des plantes. Phytopathologia Mediterranea 34(3): 143-148.

18. Blat SF, da Costa CP, Vencovsky R, Sala FC (2005) Inheritance of reaction to Leveillula taurica (Lev.) Arn. in Capsicum baccatum. Crop Breeding and Applied Biotechnology 5(4): 467-472.

19. Blat SF, da Costa CP, Vencovsky R, Sala FC (2005) Reação de acessos de pimentão e pimentasao oídio (Oidiopsis taurica). Horticultura Brasileira 23(1): 72-75. 
20. Blat SF, da Costa CP, Vencovsky R, Sala FC (2005) Inheritance of reaction to Leveillula taurica (Lev.) Arn. in Capsicum annuum L. Scientia Agricola 62(1): 40-44.

21. Blat SF, da Costa CP, Vencovsky R, Sala FC (2005) Hot pepper (Capsicum chinense, Jacq.) inheritance of reaction to powdery mildew. Scientia Agricola 63(5): 471-474.
22. Kim S, Kim DH, Kim DH, Han KS, Han YK, et al. (2011) Development of Resistance Evaluation Method for Powdery Mildew (Leveillula taurica) in Capsicum spp. Research in Plant Disease 17(3): 311-316.
This work is licensed under Creative

Commons Attribution 4.0 License

DOI: 10.19080/ARTOAJ.2018.14.555923

\section{Your next submission with Juniper Publishers} will reach you the below assets

- Quality Editorial service

- Swift Peer Review

- Reprints availability

- E-prints Service

- Manuscript Podcast for convenient understanding

- Global attainment for your research

- Manuscript accessibility in different formats

( Pdf, E-pub, Full Text, Audio)

- Unceasing customer service

Track the below URL for one-step submission https://juniperpublishers.com/online-submission.php 